\title{
Student som allmennlege
}

\author{
Det skjer noe med legestudentene i Troms $\varnothing$ i 5. studieår. Jeg har sett dem komme tilbake etter endt praksis- \\ periode, og forandringen er ikke til å ta feil av. De er ikke bare studenter lenger. De er i ferd med å bli leger.
}

Nå har jeg opplevd forvandlingen selv. Jeg har vært fire måneder i praksis på et lokalsykehus, og to måneder i allmennpraksis i en distriktskommune. På sykehuset jobbet jeg med samme type oppgaver som turnuslegene, men med mer oppfølging og mindre ansvar. I allmennpraksis hadde jeg eget kontor og egne pasienter. I kontoret ved siden av satt veilederen min. Det var alltid mulig - og forventet - at jeg konfererte med henne. Jeg har møtt pasienter tidligere i studiet også, men nå var det på «skikkelig» for første gang. Nå tok jeg på meg legefrakken og møtte pasientene på egenhånd.

Før jeg dro i praksis, visste jeg lite om hva det ville si å være lege. Hva måtte jeg egentlig mestre i legehverdagen? Umerkelig har holdninger, vaner og uvaner krøpet under huden. Og kanskje en selvfølelse, mer enn noe annet: «Sånn er det å være lege, og sånn er jeg som lege.» Jeg har fått avstemt meg selv mot virkeligheten - nå vet jeg mer om hva jeg kan og ikke kan. Jeg vet noe om hva som er viktig og hva som er mindre viktig. Jeg har vært på vei mot legerollen gjennom de første fire studieårene, men det er først nå jeg har tatt steget og rollen fylles med innhold.

\section{Skjellsettende opplevelser}

Inntrykkene fra disse første erfaringene er sterke. De drukner ikke i andre erfaringer og forutinntatthet. De blir til referanserammer som kanskje blir stående en god stund. Veilederne vi møter i denne tiden er også helt avgjørende. De har mulighet til å være med på å forme oss til gode fremtidige leger. Jeg er ikke i tvil om at en slik læringssituasjon har vært med på å løfte utdanningen min til et nytt nivå. For første gang i løpet av studiet har jeg blitt sett og det er blitt stilt krav til meg. Frem til nå har det vært lett å stikke seg bort, blant hundre medstudenter i en forelesningssal eller i en stor gruppe på sykehuset. En-til-en-undervisningen har vært uvurderlig. Ikke bare har læringskurven vært stupbratt, men jeg er blitt tryggere på hvem jeg er og hva jeg har å komme med.

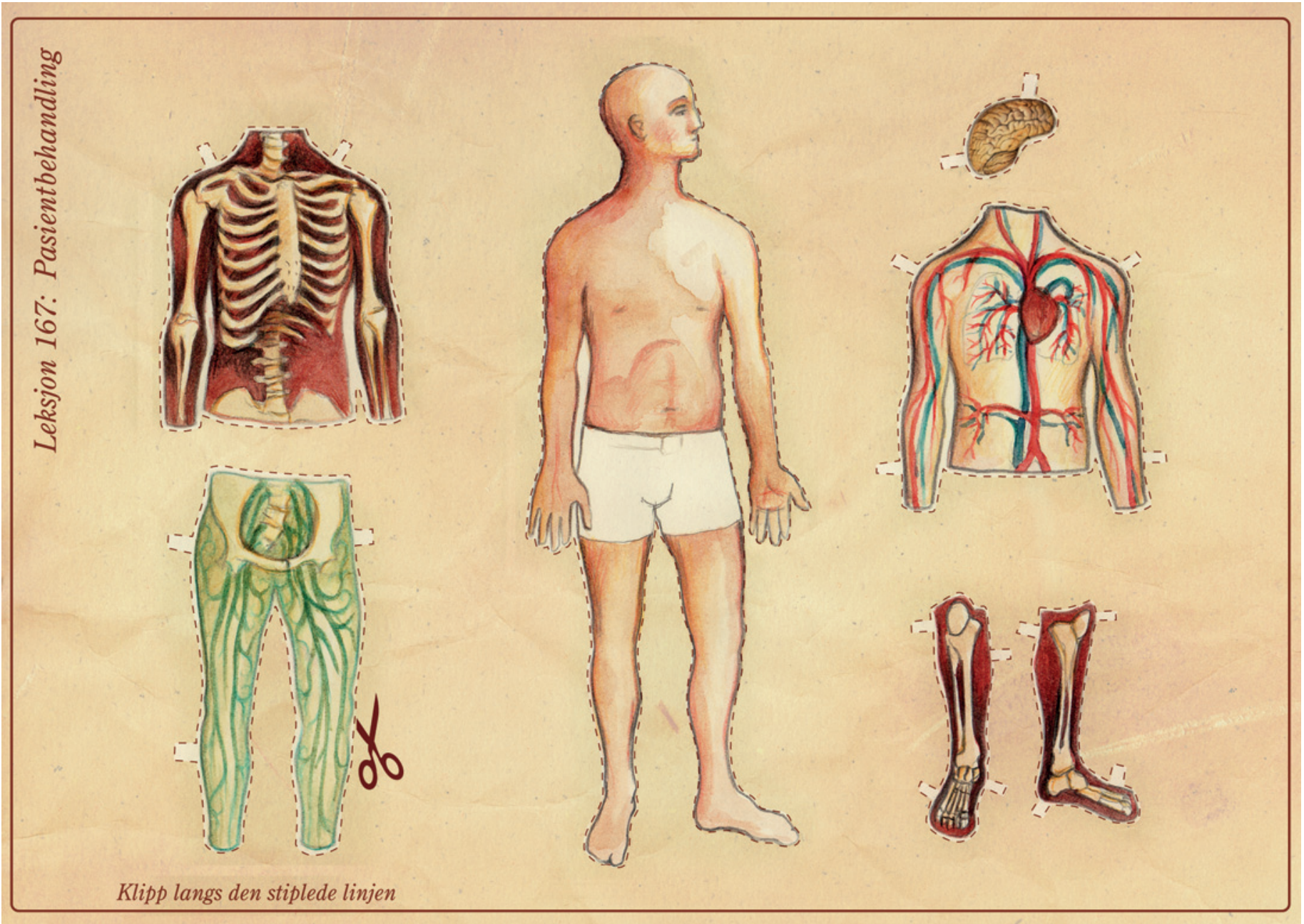




\section{Fra teori til praksis}

En praksisperiode handler ikke bare om endelig å få anvende teorien vi har tilegnet oss på skolebenken. Det handler først og fremst om å lære det som ikke kan læres fra en bok eller fra en foreleser. Det er nemlig ikke møtet med diagnoser og avansert utredning som blir viktig i denne tiden. Det er ganske enkelt mennesker som møter meg i min nye rolle som lege. De møter meg med et virvar av behov og ønsker og livshistorier. Og der sitter jeg fersk bak kontorpulten - i en rolle det er knyttet forventninger til. Er jeg rustet til å møte dem? Har årene på skolebenken lært meg å møte mennesker i sorg, smerte, familiekonflikter og ensomhet? Syke mennesker er sårbare mennesker, og det er slik de møter meg. Jeg oppdaget at jeg ofte ikke hadde mer å tilby enn å lytte.

Det er vel ikke underlig at jeg som student følte at jeg ofte ikke strakk til. Men jeg spør meg om det finnes en allmennlege som ikke av og til har følt seg utilstrekkelig i møte med menneskelige problemstillinger? I løpet av mine to små måneder på et allmennlegekontor møtte jeg i alle fall mange pasienter som jeg følte at jeg kom til kort overfor.

\section{Pasienten - mer enn et sett organer}

I studiet har vi lært om kroppen gjennom organbaserte kurs. Vi har lært om sykdomsprosesser, utredning og behandling for hvert enkelt organ. Vi har hørt om uvanlige diagnoser som spesialisten en sjelden gang har møtt på sykehusavdelingen. Visst har vi også hørt om «verden der ute» i samfunnsmedisinkursene. Vi har fått høre at den ikke er like forhåndsdefinert som på avdelingen, og at det er en utfordring å kjenne igjen de «virkelig» syke. Men hva med alle dem man bare ikke forstår hvordan man kan hjelpe? Alle dem som ikke passer inn i rammene av den skolemedisinen vi har lært? Det er mange av dem i allmennpraksis. Hvilke redskaper er vi utstyrt med for å mestre det?

\section{Fremtidsvyer}

Dette er ikke først og fremst en kritikk av medisinstudiet. Det er mer et sukk over alt det vi ennå ikke forstår i medisinen. Jeg håper at jeg om 50 år kan se tilbake på begynnelsen av karrieren min som lege og si: «Tenk alt vi ikke forsto da. Tenk at vi skilte mellom psyke og soma!» Mitt håp er at fremtidens medisinstudier i enda større grad klarer å knytte sammen fagfelter og lære oss studenter å se sammenhenger. Så blir det vår oppgave som leger å fortsette arbeidet med å øke forståelsen av hele mennesket.

\section{Rebecca A. Hetland}

hetland.rebecca@gmail.com

Tromsø

Rebecca A. Hetland (f. 1981) er medisinstudent ved Universitetet i Troms $\varnothing$, 5. studieår. Hun er ferdig med halvårig praksisperiode ved Kirkenes sykehus og Hattfjelldal legesenter.

Forfatter har fylt ut ICMJE-skjemaet og oppgir ingen interessekonflikter.

Mottatt 2.5. 2012, første revisjon innsendt 16.5 . 2012, godkjent 25.5. 2012. Medisinsk redaktør Kristin Viste. 